\title{
The Influence of the Ecumenical Movement of the XIX Century on the Formation of the Universalist Ideology
}

\author{
Anna Shestakova \\ Post-graduate student, Department of Modern and Contemporary History, \\ Institute of History and International Relations, \\ Saratov State University \\ Russian Federation \\ E-mail: ashestakova@mail.ru
}

\section{Doi:10.5901/mjss.2013.v4n11p784}

\section{Abstract.}

At the core of the majority of today's socio-political and military conflicts lies one reason - the national identity crisis has caused a sharp conflict of values, which, in turn, is the consequence of globalization. The religious norms play the most important role in the formation of a person's sense of identity. The consideration of the ecumenical movement in the XIX century is indicative for the analysis of the process of globalization, as the Christian church was the forerunner of the universalization through the call for ecumenism. The purpose of this article is to identify the genetic relationship between the properties of ecumenism of the XIX century and the main characteristics of universalization. The method of research is historical-genetic. The study includes the analysis of the dialogue between the three largest Christian confessions - Roman Catholic, Orthodox and Anglican churches. A wide range of historical sources (letters, diplomatic documents, articles) related to the investigated period has served as the research material. The analysis led to the conclusion that the concept of "ecumenism" underwent a radical change during the XIX century, becoming a specific half-secular ideology akin to the concepts of "liberalism" and "postmodernity". Herewith, each of these confessions was guided by its own choice of behavioral strategies by special, peculiar only to it, motives, which largely determined the specific national, country and regional identity of $X X-X X I$ centuries.

Key words: ecumenical movement, universalization, Christian churches, national identity, postmodernity.

\section{Introduction}

The logic of the development of modern civilization creates ideological phenomena. The seeable victory of the capitalist mode of production over the socialist generated a strong belief that there is no other way of the development of the society, rather than be based on capitalism. Francis Fukuyama in his famous book "The End of History and the Last Man" substantiates the idea that humanity has come to a perfect (with a few reservations) form of government - liberal democracy (which at the same time, using the terminology of K. Marx, is a superstructure of the capitalist economic organization), and consequently there is nothing more to aspire. But capitalism as an ideology is a product of Western mentality ${ }^{1}$. Thus, having gained a victory's wreath, it pretends to supremacy on planetary scale that in practice means the dictatorship of the values inherent in Western world view.

The development of the universalist process suggests that people of the future will exist in some kind of a planetary society, and the citizens' worldview, for example, in Latin America, will be identical to the worldview of the inhabitants of the African continent. At the same time the values of the future will be equivalent or nearly equivalent to the values of modern Western civilization. Consequently, with a new force there renewed the debates about the legality of universalism, existing only in the coordinate system of Western ideology, as this process caused the growing crisis of national identity of the world communities, often resulting in bloody clashes.

\footnotetext{
1 Here and below, the definition of "Western" refers to the arbitrary definition of socio-cultural type, the main characteristic of which is to focus on rationalism. It is important to note that this is not a geographical term, however, in accordance with its contents, it can be attributed to the country, which bases its own cultural and social life on a rationalist philosophy with its main distinguishing characteristics: individualism in the field of spiritual and personal, and liberal democracy in the political sphere.
} 
Long-term secularization of public life led to the fact that the fundamental concepts of modern society, such as "equality" and "freedom", were considered the "invention" of the Renaissance or Enlightenment, or of the latest world policy. In fact, and it is not a recent discovery, the "copyright" here belongs to Christianity, as well as the universalization of the modern world which has originated among others from the ecumenical movement ${ }^{2}$. Unfortunately, the history of ecumenism is considered often in isolation from the context of actual events of everyday life, because it is viewed as the prerogative of the narrow experts. This approach, in my opinion, does not take into account the enormous importance of this factor for the development of the so called "collective unconscious" of the modern world. The XIX century has the particular importance for the topic of article, because this century developed strategies and ideological concepts which we use successfully in the XXI century. Moreover, these attitudes formed a century and a half ago, have become something natural, "eternal" in the public mind. The historical analysis of the origin of these concepts is of great value, as it helps to avoid incorrect interpretations.

In this paper I want to show how Christian church responded to the challenges of modernity, changing its own behavior and strategy, and how the church became one of the leaders in the worldwide movement of union, as though "having sanctified" the nascent globalization by its authority. The paper consists of four sections, each of which is dedicated to the most important aspects of the ecumenical movement in the XIX century. The tools of the historicalgenetic method allowed to systematize similar and distinctive features of ecumenism and modern universality with the greatest possible clarity. This paper is based mainly on the authentic sources. The detailed analysis of the transformation of the ecumenical policy of the Holy See, made by A. Dobroer (Dobroer, 2005) was of great help. Some Englishlanguage sources of section 2.1 have been not available to me in the original, so I used them in Russian translation.

\section{Breath of future: practicality vs. dogma}

"We have a lot of men... who want to see our church united by close ties of love with the Holy Eastern Church..." - these are the lines from a letter of Bishop of the Episcopal Diocese of Western New York William H. Delancey to Orthodox Patriarchs (Delancey, 1882). The most active period in the modern history of interfaith dialogue between the Orthodox and Anglican churches occurred in the 1840s and 1870s. It developed in two complementary ways: by itself the Church of England, the Mother Church of the Anglican community, and by the American Episcopal Church. Each of them guided by both different, at the same time, similar motives.

Inside the Church of England increased the famous "Oxford Movement". The leaders of the "Oxford Movement" formulated a "branch theory", according to which the Eastern Orthodox, Anglican and Roman Catholic Churches are the three branches of the Catholic and Apostolic Church on the ground "that it continues to hold the faith of the original undivided Church, and to maintain the apostolic succession of its bishops" (The Oxford Dictionary of the Christian Church, 1997, p. 232). Some particularly impressed with the new idea activists of the "Oxford Movement" began to bow down in front of Rome and the institution of the papacy, denying the possibility of an original way for Anglicanism. Orthodox protopriest and prior of the embassy church in London Evgeny Popov cited in his letter to the Procurator of the Holy Synod Earl N. Protasov some words of «the learned Oxfordiens»: «Rome in its degree is to be considered the model. Rome as she is must be the actual model in religion. The Pope is the Christ's ambassador on the Earth... the holy see is the proper medium of communion with catholic church» (Protopriest Popov, 1904, p. 600). However, the issue of identification of the English nation with Roman Catholicism on the state level threatened the sovereignty of Britain in the eyes of the British public figures, and it was doomed to failure primordially. Accordingly, the recognition or nonrecognition of the correctness of the Roman Catholicism' foundations in British circumstances could be only a private affair of individuals, but no state church program.

In the case of the Orthodox Church, it was not so univocal. Surprisingly, the idea of union with Eastern Orthodox churches received support even on the side of the big policy: at this time British foreign policy interests were bonded with Greece. It was a "side effect" of anti-ottoman policy of the Great Powers, tried to solve the "Eastern Question", which was, as a matter of fact, the struggle between Britain and Russia for influence in the Balkans and the Middle East. It is not surprising that some of the British bishops began to look lux ex Oriente. In order to "spread in the English society the correct and accurate information about the status and situation of the Eastern Christians", as well as "to acquaint Christian brothers from East with the teachings and the beginnings of the Church of England» (Lopukhin, 1882, p. 99),

\footnotetext{
2 The term "ecumenism" was introduced into science only in the XX century. Until that time, from the point of view of scientific terminology, it would be appropriate to speak of "interconfessional contacts". However, for the sake of convenience, I will use the terms "ecumenism" and "ecumenical movement" in relation to the events of the XIX century.
} 
were created in Britain "Committee for Relations with the Eastern churches" ("Greek-Russian Committee"), and The Eastern Church Association.

The Greek-Russian Committee was organized in the U.S. Episcopal Church in 1862, too. At that time American Church was going through its second revival. The development of the idea of religious centralism was, among other things, the result of the end of the Civil War in North America, "...small sects began to disintegrate... major religious communities absorbed small... large communities themselves, because of public request, had to re-examine your inner self" - so were these events treated in Russia (Lopukhin, 1882, p. 687). As in Britain regarding Anglicanism, in America began to speak highly skeptical views about future of Protestantism. In the 1860s the sermons about "bankruptcy of Protestantism" and calling the "catholicity" as the only salvation from the moral failure became popular. But the most serious cause of American bishops' appeal to the Eastern Orthodox hierarchs was the purchase of Alaska in 1867, as recorded in the official report of the American Greek-Russian Committee, "[need] to communication caused by the fact that we have recently acquired a large Russian territory, with its bishop and forty other spiritual entities to which our immigrants could apply for the execution of pastoral ministry - in visiting the sick, burial of the dead, committing a wedding, baptism of children and the like" (The Report of the North American Greek-Russian Committee, 1882, p. 124). One of the members of the North American Greek-Russian Committee made a trip to Russia, where he was greeted the higher church dignitaries warmly. On the wave of public goodwill in 1870 in New York City was opened the Russian Orthodox Church. Although officially it was allowed to the prior of that church Nicholas Bierring to attend the service at the Anglican churches only, eyewitnesses confirm the participation of Father Nicholas in some Episcopal Church' ceremonies. However, a welcoming alliance did not happen. The main reason for the failure of negotiations, I think, has nothing to do with theological controversy.

From the beginning, British and American bishops did not mean the union of the churches in the sense of a full merger. For example, the report of British Greek-Russian Committee for 1867 declared: "It is not, as many think, the merger of one church with the other, it is not the question about our submission to the authorities of Eastern Orthodox Church, or the requirements of a similar submission from thereof. Likewise, it does not mean to add to our church some teachings, rituals or ceremonies peculiar to other churches, or, on the other hand, demand from them the abandonment of what seems us superfluous in them... No, in the communion, which we are looking for, there is a mutual recognition that all the churches that are similar in having a true episcopacy, are similar in the sacraments, and are similar in their faith should be, after its unification, in general Lord, to accept each other in full communion in prayer and the sacraments..." (The Report of the British Greek-Russian Committee, 1882, p. 122). From the point of view of theology, this is a very controversial statement, because the unity of churches without the identity of the sacraments and the creed is converted into an abstraction. It seems that the beginning of globalization was the real cause of efforts. Herewith, maybe, it not was perceived by the participants as the main motive. Scientific and technological progress has accelerated life on the planet. Travel, so dangerous and long before, in the middle of the XIX century, thanks to the steam engine, became much faster and more comfortable, which is why ridership has increased significantly. "The trip across the sea" was gradually becoming commonplace, more and more people were breaking out of the closed world of their village, town, community, and were going literally into other people's worlds. Thus was conceived the modern concept of "tolerance" that required forbearance, in particular, to the characteristics of the religious life of others.

In particular, it was important for the Britain, a maritime power, which had its outposts around the globe and, of course, in large numbers - in countries with prevalence of the population professing Christian faith of the Eastern Orthodox sample. Proof of this is the resolution adopted by the British Greek-Russian Committee, which denotes the next goal of the negotiations: "In consideration of the large number of members of the Church of England, staying in the east, in places very remote from the stations of our chaplains, as well as many of our seamen employed extensive trade in the Levant and the Black Sea, which die there without any opportunity to meet their religious needs on the part of our clergy, the committee finds that the only way to avoid the burial of such persons in unconsecrated ground without a word of Christian hope and prayer may be just the thing to rites Christian burial was made over them by local Orthodox clergy" (Cit. by: Lopukhin, 1882, p. 707). In fact, the goal of the Anglican bishops was pragmatic. Alongside with this objective were chosen the means of interaction - the spiritual assistance to each other in case of emergency, without unity in the dogmas.

At the same time, for the Oriental Churches the union was the visible realization of the Christ covenants about the Church's unity on earth: "...we have to stretch our hand friendly to the help of God to join together what has been divided, and to fulfil the words of the Savior..." - wrote the Patriarch of Constantinople Anfim to Charles Hale, the Secretary of the North American Greek-Russian Committee (Ecumenical Patriarch Anthimus VI of Constantinople, 1883, p. 354). All messages of Eastern Orthodox hierarchs breathe for this sacred rapture, for example, here is an excerpt from a letter of 
Archbishop Theophilus of Athens: "The desire and prayer of the Episcopal Church in America were the messengers of unspeakable joy... at the sight of rising expectations of fraternal rapprochement and reunification of the Christ's Churches, which for so long prayed" (Archbishop Theophilus of Athens, 1883, p. 359).

Because of the immediately discovered difference of purposes between the two parties, misunderstanding grew faster and faster. Oriental clergy sincerely did not understand why, officially recognizing the lack of Filioque in the Creed of Constantinople Ecumenical Council (The Report and the Resolution of the North American General Convention of the Episcopal Church in 1874, 1883, p. 374), the Episcopal Church had still not banned it for believers. Anglican bishops, in turn, were genuinely surprised by the persistence of Orthodox clergy in the abolition of Filioque, which, in their opinion, was not a significant item to take risks of calm their communities because of it. Gradually the communication subsided, the Greek-Russian committees were dissolved and soon the Orthodox Church in New York City was closed.

\section{Association or merger: the difficulties of definitions of the model of ecumenism of new time}

The dialogue about the union between Old Catholics and the Russian Orthodox Church looks quite different. From the beginning, these negotiations did not carry a discernible practical element and had a distinct theological consonance. Old Catholic movement set up on its own after the Vatican I (1869-70) through the non-acceptance of a part of the Catholic clergy the dogmas of the Papal infallibility and of the Immaculate Conception of the Virgin Mary ${ }^{3}$. In Russia the news about the separation of a group of believers from the Roman Catholic Church was met with understanding. There was a kind of party of supporters of association with the Old Catholics; the personality of Johann von Döllinger, one of the leaders of the Old Catholic movement, aroused particular sympathy. J. Döllinger called the divided state of Christianity, especially in Germany, "the great drama of history" and believed that the union of the church was much more natural than the separation (Döllinger, 1888, p. 31). Old Catholic priest Aloysius Anton wrote in 1872: "...we are fully convinced that the Greek Church is much closer than the Roman Church to that ancient church, which is ideal for us and the ultimate goal of our aspirations» (Priest Aloysius Anton, 1872, p. 135).

The affair took an official character: a special commission of the Holy Synod considered the possibility of reunification after the response of the Old Catholics to quaestionum controversarum. Old Catholic clergy, having completed theological research, acknowledged that the major stumbling block to reunification - Filioque - is not a dogma, but a private opinion of some theologians. In 1874 and 1875 Conference on unification held in Bonn, where took part the Orthodox clergy and theologians. In 1875 by Old Catholics was published "Guide to Learning the Orthodox faith in the institutions of higher learning". Russian supporters of union with the Old Catholics have tried to find a political reasonableness of this act. For example, General A.A. Kireyev wrote to Nicholas, Bishop of Alaska and the Aleutian: "...for us, Russian, Old Catholicism has another special meaning. This is the key to the solution of the Polish question". If we could move our Roman Catholic Poles - in Old Catholicism, Polish question would be resolved eo ipso» (Kireyev, 1911, p. 1351).

However, the problem of the union between Russian Orthodox Church and Old Catholics remained "in limbo". The reasons for non placet may have served the active negotiations of Old Catholics with the Anglicans about the union, and also (as in the case of the Anglican Church) the unwillingness of Old Catholics of complete merger with Eastern Church. This is explicitly stated in the "Invitation to the first Bonn Conference" (1874), which was written by J. Dellinger: "The immediate aim, which the conference should contribute, there is no all-consuming union (absorptive Union), or complete merger of the various religious bodies (Kirchenkoerper), but the recovery of ecclesial communion on the basis of unity in the required (unitas in necessariis), with savings and retaining those characteristics of individual churches that do not belong to the essence of the ancient church" (Cit. by: Bolotov, 1893, p. 101). J. Reinkens, Old Catholic bishop, accentuated at the Bonn conference in 1875: "I remind you... that in fact none of us are thinking to move to the Eastern Church" (Cit. by: Ibid.). For the Orthodox churches such an approach was unacceptable.

On the contrary, the dialogue between Old Catholics and Anglicans ended the conclusion of "intercommunion" in the XX century. The material terms of "intercommunion" were the recognition of the independence of each of the parties provided the resolving of the participation of believers in the sacraments. In the context of the article it is important to note: it's hardly an accidental fact that Old Catholics and Anglicans (representatives of Western Christianity) came to a common understanding of the "unitas in necessariis", while Eastern Christians strongly rejected this formulation. It is

\footnotetext{
3 The origin of Old Catholic movement dates from the XVIII century. Further information: Sokolov, 1897. However, since the consideration of the beginning and the growth of Old Catholic movement is beyond the scopes of this paper, I will confine myself to the statement of the official separation of the Old Catholics after Vatican I.

4 On the essence of "the Polish question" for Russia, see below.
} 
impossible not to see here the effects of the similar world outlook, due to centuries-old spiritual, geographical, economic, social and political ties, that is what is called a "common historical path" and determines, ultimately, the regional specificity. Under favorable conditions, which created the emerging globalist ideology, the factor of "a common historical path" was stronger than the dogmatic controversies.

\section{Metamorphoses of ecumenism in "Roman version"}

Without belittling the sincerity of attempts of Anglicans and Old Catholics to unite with Orthodox Church, it should be noted that in all of these negotiations elusively and perhaps even unconsciously, played a motive, other than the above: the desire to join forces against the might of the Vatican. Objectively, in the world of the XIX century only Eastern Orthodox Church, and, in particular, Russian Orthodox Church, could compete with the Vatican - in theology, politics, etc. The undeniable advantage of Orthodox churches was the centuries-old existence without Rome, proved their strength and vitality. It was a real alternative to the Vatican; consequently the seductiveness of the alliance with Orthodox Church looked even more prominent. This elusive desire is articulated most clearly by the Russian general A.A. Kireyev: "...no doubt that the affair of the Old Catholicism and of the Orthodoxy - is one and the same thing, we have the same enemies (the Jesuits) and the same desire... - restoration of church unity, infringed by Rome...» (Kireyev, 1911, p. 1351). In another letter he wrote that the negotiators were on "advanced fortifications against the Roman camp" (Kireyev, 1911, p. 1500).

In its turn, the Holy See in the XIX century was active in their actions to unite with the Eastern Orthodox churches ${ }^{5}$ as never before. The documents relating to this period, clearly demonstrate a watershed in ecumenical politics of the Vatican, which appeared with the beginning of the pontificate of Leo XIII. We can see how in a very short time lapse the authoritarian-demanding regime of monologue of encyclicals transformed into a dialogical narration in the spirit of "kinship and intimacy". In the absolutist paradigm were written the most famous letters of Pius IX: the encyclical «In suprema Petri» (1848) and the Dogmatic Constitution «Pastor aeternus» (1870). The first document, although it promises to preserve the Orthodox Liturgy in the event of reunion, however, places the blame for the schism completely on the Eastern Church. It was written, according to A. Dobroer, in the spirit of "soteriological exclusivism" (Dobroer, 2005, p. 101), offensive to the eastern Christians. Soon there followed a very sharp response by the Orthodox patriarchs. Eastern bishops accused the Bishop of Rome of the thirst for power, as well as the deliberate distortion of the Sacred tradition: "As for the supremacy, about which there was a lot of noise and disputes, to which lays strong claim, which rises and extols and which the Bishop of Rome threatens, as a cloud thunderbolt, then we tell the truth, it does not prove the writings of the Eastern Fathers and the Eastern Church has never accepted that it has the power, as the bishops of the Roman philosophize" (The Reply of the Orthodox Eastern Church, 1849, p. 51). Eastern patriarchs still gave the Bishop of Rome only the primacy of honor, but not the primacy of jurisdiction.

The deep conviction of Pius IX in the necessity and the legality of full power of the Holy See was reflected in the Dogmatic Constitution «Pastor aeternus». In it Pius IX canonized the provisions which were the subject of a centuries-old dispute with the Eastern Churches, namely the supremacy and full jurisdiction of the Successor of the Prince of the Apostles and the priority of the Bishop of Rome in front of the Ecumenical Councils, vowing the ban to all dissenters. Even the canonization of these controversial provisions has been able to cause a storm in the Christian world. But the real odium the document acquired thanks to the famous dogma of the infallibility of the Pope's statements ex cathedra. The new dogma has not only added the arguments to opponents of the Holy See, but it has also split Roman Catholic Church itself - Old Catholics separated from it, until today they have not accepted "the Papal infallibility".

However, the merit of abolition of praestantia ritus latini in the official ideology of the Roman Catholic Church belongs to Pius IX. Still, back in the encyclical «In suprema Petri» he wrote: "We shall maintain intact your particular Catholic liturgies; as We value them greatly, even as they differ in some ways from the Latin liturgy. Our predecessors always held them in great esteem due to the venerable antiquity of their origin, the languages employed by the Apostles and the Fathers and in which they written down, as well as the magnificence of their rites, truly suited as they are to nourishing the piety of the faithful and to imbue them with respect for the divine mysteries" (Pope Pius IX, 1848). At first

\footnotetext{
5 Under the term "association of churches" in this section I mean the union of the Roman Catholic and Eastern Orthodox churches, not touching the dialogue between the Vatican and Protestant churches. The Holy See has never refused to accept the Protestants back into the bosom of the Roman Catholic Church, but only under the condition of complete repentance of delusions and acknowledgment of the Vatican's primacy in matters of dogmas and liturgy. When the question is put so the discourse could be just about the absorption of the Protestant churches by the Vatican, but not about their association.
} 
sight, this detail is important only for historians of the church. However, it really is another step to tolerance in the modern sense.

For all this, the fact that Pius IX remained an apologist for the Latin Canon law prevented the relations with the Eastern churches. In encyclicals "Quae in patriarchatu» and "Quartus supra», addressed to the Chaldean and Armenian Eastern Christian churches, he emphatically declared: "Nor can the Eastern Churches preserve communion and unity of faith with Us without being subject to the Apostolic power in matters of discipline" (Pope Pius IX, 1873). This is an extremely important point to which I will return shortly.

Just 10 years passed since the publication of «Pastor aeternus», and the Holy See published a very different in spirit encyclical «Grande munus». In it Rome appealed to Eastern Christians in the following terms: "We thank God for giving Us this suitable occasion to thank the Slavic people and to effect a common benefit for them" (Pope Leo XIII, 1880). Despite the fact that the text referred to the schism: "May there be constancy in all Catholic men and the will to reconcile all dissidents to the true Church" (Ibid.), however, the tone of the encyclical and the occasion on which it was written (appointment of the special day to honor the memory of the Slavic missioners Cyril and Methodius, who are significant figures in the pantheon of heroes of the Slavic countries), aroused sympathy to the Pope among Eastern Christians. The encyclical «Grande munus» is seldom considered under such foreshortening, but I believe that, in the context of the history of the Roman Catholic Church, it continued "In suprema Petri", mounting stylistically an accomplished change. Since the "Grande munus" the offensive to Eastern Christians tone leaves the encyclicals of Bishops of Rome.

In 1894 the three "ecumenical" encyclical were published: «Praeclara gratulationis», «Christi nomen» and "Orientalium Dignitas». Among them it is necessary to distinguish the latter. Returning to the issue of priority of the Latin Canon law, it must be said that the encyclical «Orientalium Dignitas» made a real revolution in this matter. Leo XIII recognized the value of the Eastern Church law and declared the opportunity of the priority of specific canons in the Eastern Christian dioceses: "Inasmuch as this diversity of liturgical form and discipline of the Eastern Churches is approved in law, besides its other merits, it has redounded tremendously to the glory and usefulness of the Church" (Pope Leo XIII, 1894). This was the final step in strengthening of the globalist thinking in the church ideology.

The feature of «Orientalium Dignitas» was immediately noticed in the Orthodox world: "...Leo XIII throws off the greatness and acts humility as a "servant of the servants of God", - wrote A.P. Lopukhin, a Russian writer and theologian (Lopukhin, 1895, p. 112). On the pages of Russian Orthodox press appeared the responses, clearly showing sympathy to the pope, but at the same time they reflected skepticism about the real embodiment of good intentions of Leo XIII: "Some popes might even make formal orders to the need to spare and to respect the ritual features of the Uniates, but in reality the Romanization continues its destructive work, as if such regulations have never existed, because the papacy as the system is infinitely stronger than single popes" (Ibid. P. 115.). The encyclical received the official response of the Patriarchs, which, although in a relaxed expression as compared to the letter of 1849 , but it still noted the "spirit of excessive vanity" of the bishops of Rome and declared that as long as Rome did not give up "illegal and contrary to the Gospel innovations", "all discourses about the union will be idle and vain" (The Patriarchal and Synodal Encyclical letter, 1895, pp. 1, 3).

The sharp response of the Orthodox hierarchs was not just "a tribute to the past": proselytism of Rome outraged Eastern Christians utterly. The Holy See was accused of Uniatism, during which the "deceitful workers", transforming themselves into the apostles of Christ, wearing clothes of Orthodox priests» (Ibid.), realized Romanization of Eastern Christian population. Often the process of Romanization was accomplished without the due consideration of religious traditions: the report of Cardinal Langénieux, appointed legate to the Eucharistic Congress in 1893, stated "the triumphalist behavior of the Latin clergy" (Dobroer, 2005, p. 104). The Orthodox observers wrote: "[Roman court] looked at the union, as a temporary deal, as the first step towards full accession of the Uniates to the Roman Church" (Popov, 1868, p. 28). And here we come to consider an essential element of ecumenism of the XIX century - the ideological policy of the Government of the Russian Empire.

\section{5. "Persona sui generis"}

Previously Roman ecumenical policy was considered in isolation, as the concentrated form helped to visualize the scale and the true meaning of ideological transformation. However, this analysis is not complete, because it ignores the Vatican relations with Russia - "the blessed" Russian Empire, the largest Orthodox country with a "particularly great and glorious Church" (The Patriarchal and Synodal Encyclical letter, 1895, p. 17), the ideological heir of Byzantium, which played an extraordinary role in the ecumenical movement, setting the tone for the entire Orthodox community. 
Despite courtesy of diplomatic correspondence and even the conclusion of the Concordat, in general, the relationship of the Russian Empire and the Vatican in the XIX century can be characterized as follows: à la guerre comme à la guerre. It was promoted by a range of reasons.

First, Russia for the Modern History thought herself a stronghold of Orthodoxy and the guarantor of its rights in the world. It was believed that Rome received the deserved punishment from heaven, while Moscow - the "third Rome" prospered. Why did, in that case, the thriving "third Rome" was to take something from the "fallen Rome", not used its historical chance?

Second, the peculiar geographical position of Russia contributed to the permanent state of war because Russia appeared geographically in the role of a "bridge" between Europe and Asia. The reflection of a particular civilizational paradigm of Russia can be seen in the following lines of one of the largest and most popular in the XIX century Russian magazines "Herald of Europe": "Russian people, from the very first days of its historical existence, defended their national and state independence and the universal church from two enemies: on the one hand, from Asiatic barbarism... on the other - from the Latin West. In this last fight the instigator and leader of the time was Rome» (Popov, 1868, p. 24). Thus, the Roman Catholic Church for Russian rulers meant not just one of the branches of Christianity, but the quintessence of the Western way of thinking, Rome was considered the mastermind behind the Western secular states with which Russia had a difficult relationship. The question of union between Western and Eastern churches, or even just their communication, in fact, was seen as an encroachment on the state sovereignty. As a result, the process of negotiations between Russian Orthodox Church and the Holy See was heavily politicized.

The question of establishing any contacts with the Vatican was seriously considered in Russia after the invitation of German colonists by Catherine II to the territory of the Volga in the XVIII century, as well as after the partitions of the Polish-Lithuanian Commonwealth, so that a large number of Catholics became the subjects of the Russian crown. In the effort to prevent the influence of an alien ideology on the Russian mentality, the government did everything to prevent the propagation of Catholicism in the empire. Empress Catherine II issued a decree that before the promulgation papal bulls must have received the approval of the government. The peculiarity of Catholic canon law was the source of strong irritation: "...the Catholic Church within the Russian Empire is a special state, subordinated only to the Pope, and in the affairs of which any other authority can intervene, but to the extent of what the Pope will approve of" (Popov, 1868 p. 33). Imperial absolutism was not going to put up with a "Catholic absolutism", therefore Paul I created the Roman Catholic Department of the Collegium of Justice, where both were the laymen. After the reorganization the Department was called the Roman Catholic Theological Collegium, then the Department of Religious Affairs of Foreign faiths, but essentially it did not change. Imperial Court considered Catholic priests if not spies, but at least as the "fifth column", ready to collapse at the worst possible moment, and with good reason: there is historical evidence that during the Patriotic War of 1812 some Russian Catholic bishops supported Napoleon (Tolstoy, 1877, p. 429-430). But the most painful blow was the behavior of some Catholic priests during the Polish uprising of 1830-31: "...ecclesiastics, of all ranks, forgetting the sanctity of their calling, interfered in all the bloody action and were constantly at the head of the revolutionary movement and participated in hostilities" (The Note of the Envoy in Rome on April 20, 1832). This was seen as high treason, after rebellion the tsar government began Russification of Poland, which included, inter alia, the popularization of Orthodoxy. In the years 1833-75 the vast majority of the Polish Uniate parishes returned to the jurisdiction of the Russian Orthodox Church. Often the Catholic religion was the cause of the infringement of the rights of Polish population. In regard to those Poles who accepted Orthodoxy, wrote Earl Leliva, Russian officials often faced the dilemma of how to define "persons of Polish nationality" - by nationality or religion? (Earl Leliva, 1895, p. 8-9). On the solution of this question the properties rights of subjects of the empire depended as defined by the Act of December 10, 1865.

In spite of the persecution of the Catholic clergy in Poland, the Roman court was forced to follow in the footsteps of the policy of St. Petersburg in the Polish question, because Russia was too strong, so it could not be ignored. Therefore, in 1832, Pope Gregory XVI condemned the Polish uprising. Only in 1867, Pius IX, after a rebellion in Poland and the Russification, anathematized the persecution of the Catholic Church in Russia in the encyclical «Levate». Russian public, considering the "Polish question" as "family affair" (Pushkin, 1941, p. 169), answered in the spirit: ut salutas, ita salutaberis, justifying the right of spreading of Orthodoxy by historical fact of the existence of the Eastern Rite in the Western Slavic lands long before the Catholic and qualifying addition of the Uniate parishes to the Russian Church as the restoration of status quo, broken at the Union of Brest. In response to the allegations in discrimination of Catholicism followed recrimination in two centuries of discrimination against Orthodoxy in the West Slavic lands.

Thus, Russian public, though condemned excessively zealous secular officials who conducted the Russification of Poland, supported the state policy in general, based on the doctrine of "Orthodoxy, Autocracy and Nationality". Russian scientists, writers, theologians agreed in the opinion that the "secular ambition" (Spichakov, 1872, p. 5) of the Roman 
Pontiffs leaves no choice to the government in the direction and means of maintaining state sovereignty and sovereign power within its territory: "What can it [Catholic Church], propagandize to us? Nothing like as a papistry, as a recognition of the rule of the pope over all the Ecumenical and therefore the Russian church, as the subordination of the Russian church to the Roman Pontiff" (Aksakov, 1884), "...the Pope considers that the whole world is its state. <...> According to the teachings of popes and their canonists... secular rulers should be just the executors of his commandments" (Popov, 1868, pp. 33, 59). But that was not the only policy.

The difference in mentalities contributed to suspicion and even hostility to Catholicism, and it remains valid to this day: the logical West puts the life of society in the category of hierarchy, law, formalities, while the intuitive East with a strong tradition of contemplation and inclination to mysticism, does not recognize the understanding of the world through the mind and structuring based on the mere rationality. At the level of theology it is reflected in the struggle of two Christian teachings - the theory of the cognizable universe owned by Thomas Aquinas (which was adopted as the official ideology of the Holy See in the XIX century) and the Augustinian concept of the knowledge of the Creator in the created reality by the revelation. And if the Vatican chose Thomism, in the writings of Orthodox workers was clearly traced attraction to Augustinianism. Augustinianism in some of its features found realization in Russian spiritual eldership, which had a considerable influence with the public, sometimes even more than the official church.

In the face of this fact, the statements that only the official leadership opposed the reunions of the two churches by political reasons (quite obvious of course) - generally untenable. "Latin" faith, as this example shows the necessity of activity "in this world", was so far from Russian "people's Christianity" with its reverence of eldership, the recognition of the deep mysteries of intimacy and truth only of the "other world", that it just does not stand a chance to "settle down" in Russian conditions. Significant is the fact that even N. Gogol, who was in love with Italy and lived in it intermittently for almost 10 years, who greatly admired Rome, in respect of faith was adamant: "...as for the Catholicism - he wrote to S. Shevyryov from Naples in 1847 - that will tell you what I have come to Christ through more Protestant than Catholic way" (Gogol, 2009, p. 79).

One of the few Russian public figures, who advocated the union of the churches under the supremacy of Rome, was a famous writer and religious philosopher Vladimir Solovyov. He called the Roman pontificate "miraculous icon of universal Christianity", "evangelical rock", "mighty bulwark of the truth", and a sample of the Byzantine autocracy accused of "Caesaropapism" and "political Arianism" (Solovyov, 1911, pp. 28, 29, 32, 33 49). Following the publication of his works in the Russian press there began a debate in which opponents of the writer rejected the arguments made by him. In the end, the publicist was perceived as a renegade, a traitor of national interests and more - the traitor of the interests of true Christianity, almost heretical, blasphemous to encroach upon the foundation of faith. In the context of the paper, however, the most important point to note is that apologistancy of Roman Catholic Church remained only the very private affair of Vladimir Solovyov. Together with the blamed ideas of Vladimir Solovyov was censured the idea of Churches' Union in its "Roman edition" - this process seemed as too painful and even catastrophic for Russia's national identity.

\section{Conclusion}

The development of the ecumenical movement in the XIX century showed the evidence and the depth of intrusion of the globalist ideology in all spheres of public life. Even the doctrinal dogmas, seemed unshakable for centuries, wavered in front of the power of the new current. Like the "aqua regia", it transformed irreversibly the concept of "ecumenism": it began to include not only and not so much a church joining but a kind of universalist worldview, and with a pronounced shade of the "spirit of Protestantism" in the interpretation of Max Weber.

Exclusively church's movement towards the end of the XIX century turned into a secular in nature, and was fully developed in line with the mainstream. The most definite characteristic feature of it - the tolerance - related it to liberalism ${ }^{6}$. The emphasis on rationality and legitimacy of relying on scientific evidence (mark neo-Thomism in Roman Catholic Church) allowed to see the features of modernism. But the spirit of ecumenism of end of the XIX century was the closest to post-modernism. The acceptance of differentiated church law - is, in essence, a departure from the rigid forms of hierarchy, in the direction of the anarchic anti-synthesis of postmodernity. Dogmatic deals led to the dispersion of the spiritual power that in the new world was made "use properly". It is no coincidence that in the XX century was realized the fundamental difference between "native ecumenism" of the beginning and the first half of the XIX century, from the "new model of ecumenism" (Protopriest Razumovsky, 1948).

${ }^{6}$ It is noteworthy that S. Aleskerova came to similar conclusions, exploring the ecumenism of the XX century on the other sources. Further information: Aleskerova, 2009. 
The starting point of thinking that led to these conclusions is the fact that the ecumenical movement of the XIX century was a double even multi-directional flow, quite different in nature. One of them, we'll call it "traditional ecumenism", was the continuation of the centuries-old Vatican policy, the essence of which is to try to unite with the Eastern Christian Church under the aegis of the Roman pontiff. The core of the second course was the Anglican Church, focused on the practical aspects of using the advantages of the union. Russian Orthodox Church as a forward of Eastern Christianity was the element of attraction for both flows. A powerful factor that created the conditions for such an active combination efforts was globalization, based on the ideas of Protestantism. The spirit of Protestantism "went to the masses". In this situation, the "old" churches had no choice but to adapt, with more or less success. Particularly impressive is the transformation of the ideology of the Roman Catholic Church from the end of XIX century: Rome began to talk about parity reunion with the Orthodox Churches, which it considered worthy of honor save in the case of union of the inherent doctrinal bases, especially the liturgy and even of canon law, or at least, a substantial part thereof.

An invitation to a dialogue on an equal footing diverted the churches away from irreconcilable discussions about doctrinal issues of the Middle Ages. This process, on the one hand, contributed to the apparent association of people, on the other - leveled the unique characteristics of each religion: if all religions are equally good, and you can believe in any, then why bother to believe in the religious sense? "God the Father" in the public mind split in two, then in three, and in the XX century in even a greater number of names. And all these "little gods" themselves are immeasurably less important and are qualitatively different in nature from the original Christian "God the Father". Thus, the ecumenical movement, paradoxically, completely secularized the already secularized world.

Aware of planetary meaning of the ecumenical movement, at the same time we must note its regional influence. The conclusion of "intercommunion" between Anglicans and Old Catholics, the spread of the "Latin Christianity" in the Eastern Orthodox European countries (excluding Russia) as though anticipated the idea of the united Europe. Europeans were lighter and easier to neglect the "formalities" in the face of centuries-old of living together in a common area, a stronghold of social, political, economic and cultural ties. In contrast to the Western idea of universalization, in Russia in the late XIX century, won the idea of national identity, that still puts it in a unique position "persona sui generis" of international relations.

\section{References}

Act of the Russian Empire dated December 10, 1865, The [Zakon Rossiiskol̆ imperii ot 10 dekabrya 1865 g.]. Polnoe sobranie zakonov Rossiīskoĭ imperii. Sobranie vtoroe. T. XL. Otdelenie 2. 1865. [The Complete Collection of the Acts of the Russian Empire. Collection 2. Vol. XL. Partition 2. 1865]. (1867). Saint Petersburg. Pp. 326-328. (rus)

Aksakov, I. (1884). Against national self-denial and pantheistic tendencies expressed in the articles by V.S. Solovyov. [Protiv natsional'nogo samootrecheniya i panteisticheskikh tendentsiĭ, vuiskazuivavshikhsya v stat'yakh V.S. Solov'ëva]. Rus [Rus], №№ 6, 7, 15 march, 1 april. (rus)

Aleskerova S. (2009). The role of ecumenism in the processes of globalization (the example of contemporary Russia) [Rol' ékumenizma v protsessakh globalizatsii (na primere sovremennoĭ Rossii)]. Avtoreferat dissertazii na soiskanie uchënoi stepeni kandidata filosofskikh nauk [Abstract of dissertation for the degree of candidate of sciences in philosophy] Southern Federal University.

Archbishop Theophilus of Athens (1883). The Letter to Charles Hale, Secretary of the North American Greek-Russian Committee, on September 20, 1872 [Pis'mo afinskogo mitropolita Feofila Charl'zu Heĭlyu, sekretaryu severoamerikanskogo greko-russkogo komiteta, ot 20 sentyabrya 1872 g.]. Khristianskoe Chtenie [Christian Reading], (9-10), pp. 358-360. (rus)

Bolotov, V. (1893). The Abstract, proposed in a meeting of the Commission on the issue of old-Catholic January 22, 1893. [Referat, predlozhennuiĭ $\mathrm{v}$ zasedanii Komissii po starokatolicheskomu voprosu 22 yanvarya 1893 goda]. [online] Retrieved from: http://www.odinblago.ru/filioque/4 [Accessed: 2 Jun 2013]. (rus)

Gogol, N. (2009). The Letter to S.P. Shevyryov from Naples on February 11, 1847 [Pis'mo N.V. Gogolya S.P. Shevuirëvu iz Neapolya ot 11 fevralya 1847 g.]. In: Gogol, N. eds. (2009) Polnoe sobranie sochineniĭ i pisem v 17-ti tomakh. T. 14. Perepiska, 1847. [The complete Collection of the Works and the Letters in 17 volumes. Vol. 14. The Correspondence, 1847]. Moscow-Kiev: Izdatel'stvo Moskovskoi Patriarkhii, pp. 79-82. (rus)

Delancey, W. (1882). The Letter to Orthodox Patriarchs. December, 1863 [Pis'mo pravoslavnuim patriarkham. Dekabr' 1863 g.]. Khristianskoe Chtenie [Christian Reading], (7-8), p. 103. (rus)

Dobroer, A. (2005). Historical stages of the relations of Churches of East and West [Istoricheskie étapi vzaimnuikh otnosheniĭ Tserkvei Vostoka i Zapada]. Khrestomatiya: Pravoslavie i katolichestvo: ot konfrontatsii k dialogu [Chrestomathy: Orthodoxy and Catholicism: from confrontation to dialogue] (2005). / Ed. Aleksey Yudin. Moscow: Bibleǐsko-bogoslovskiĭ institut sv. Apostola Andreya, pp. 13-97. (rus)

Dobroer, A. (2005). Orthodox-Catholic relations in the second half of the XIX century [Pravoslavno-katolicheskie otnosheniya vo vtoroi polovine XIX veka]. Khrestomatiya: Pravoslavie i katolichestvo: ot konfrontatsii k dialogu [Chrestomathy: Orthodoxy and Catholicism: from confrontation to dialogue] (2005) / Ed. Aleksey Yudin. Moscow: Biblě̌sko-bogoslovskil̆ institut sv. Apostola Andreya, pp. 101-105. (rus)

Döllinger, J. (1888). Über die Wiedervereinigung der christlichen Kirchen. Nördlingen. (deu)

Earl Leliva (1895). Russian-Polish relations [Russko-pol'skie otnosheniya]. Leipzig: Kasprovich. (rus) 
Ecumenical Patriarch Anthimus VI of Constantinople (1883). The Letter to Charles Hale, Secretary of the North American Greek-Russian Committee on September 9, 1872 [Pis'mo konstantinopol'skogo patriarkha Anfima Charl'zu Heĭlyu, sekretaryu severoamerikanskogo greko-russkogo komiteta, ot 9 sentyabrya 1872 g.]. Khristianskoe Chtenie [Christian Reading], (9-10), pp. 354-355. (rus)

Kireyev, A. (1911). The Letter to Nicholas, Bishop of Alaska and the Aleutian, later archbishop of Warsaw and Privislenie, on 2 (14) November 1897 [Pis'mo A.A. Kireeva preosvyashchennomu Nikolayu, episkopu aleutskomu i alyaskinskomu, pozdnee arkhiepiskopu varshavskomu i privislinskomu, ot 2(14) noyabrya 1897 goda]. Khristianskoe Chtenie [Christian Reading], (11), pp. 1350-1352. (rus)

Kireyev, A. (1911). The Letter to Nicholas, Bishop of Alaska and the Aleutian, later archbishop of Warsaw and Privislenie, on July 12,1908 [Pis'mo A.A. Kireeva preosvyashchennomu Nikolayu, episkopu aleutskomu i alyaskinskomu, pozdnee arkhiepiskopu varshavskomu i privislinskomu, ot 2(14) noyabrya 1897 goda]. Khristianskoe Chtenie [Christian Reading], (12), p. 1498-1501. (rus)

Lopukhin, A. (1882). Relations between the U.S. Episcopal Church with the Orthodox East about the union of Churches [Snosheniya amerikanskol̆ episkopal'noĭ Tserkvi s pravoslavnuim Vostokom po voprosu o soedinenii Tserkveī]. Khristianskoe Chtenie [Christian Reading], (7-8), pp. 74-126. (rus)

Lopukhin, A. (1882). Relations between the U.S. Episcopal Church with the Orthodox East about the union of Churches [Snosheniya amerikanskoľ episkopal'noI Tserkvi s pravoslavnuim Vostokom po voprosu o soedinenii Tserkveì]. Khristianskoe Chtenie [Christian Reading], (11-12), pp. 687-715. (rus)

Lopukhin, A. (1895). The new papal encyclical of Leo XIII, containing in itself Apostolic constitution of maintaining and preserving the discipline of the Eastern Churches [Novaya papskaya éntsiklika L'va XIII, soderzhashchaya v sebe apostolicheskuyu konstitutsiyu o podderzhanii i sokhranenii distsiplinui vostochnuikh tserkvel]. Khristianskoe Chtenie [Christian Reading], (1-2), pp. 100-118. (rus)

Note of the Envoy in Rome Prince Gagarin on April 20, 1832, The [Nota poslannika v Rime knyazya Gagarina ot 20 aprelya 1832 g.]. (1868). Vestnik Evropui [Herald of Europe], (1), p. 30. (rus)

Oxford Dictionary of the Christian Church, The. (1997). 3rd ed. New York: Oxford University Press, p. 232. (eng)

Patriarchal and Synodal Encyclical about the papal encyclical about union churches, The [Okruzhnoe patriarshee i sinodal'noe poslanie po povodu papskol éntsikliki o soedinenii tserkveī]. (1895). Saint Petersburg. (rus)

Pope Pius IX (1848). The Apostolic Letter "In suprema Petri apostoli sede" to the Easterners. January 6, 1848. [online] Retrieved from: http://orthocath.files.wordpress.com/2010/11/pope-and-patriarchs-letters-of-pope-pius-ix-and-orthodox-patriarchs.pdf [Accessed: 11 Jun 2013]. (eng)

Pope Pius IX (1873). The Encyclical "Quartus supra". January 6, 1873. [online] Retrieved from: http://www.papalencyclicals.ne t/Pius09/p9quartu.htm [Accessed: 11 Jun 2013]. (eng)

Pope Leo XIII (1880). The Encyclical "Grande Munus". September 30, 1880. [online] Retrieved from: http://www.vatican.va/holy father/leo _xiii/encyclicals/documents/h f_l-xiii_enc_30091880_grande-munus_en.html [Accessed: 11 Jun 2013]. (eng)

Popov, $\bar{A}$. (1868). The Last Fate of the Papal Policy in Russia (1845-1867 years) [Poslednyaya sud'ba papskoi politiki v Rossii (1845-1867 gg.)]. Vestnik Evropui. [Herald of Europe], (1), pp. 23-119. (rus)

Priest Aloysius Anton (1872). The Letter on August 6 (July 25), 1872 [Pis'mo svyashchennika Aloiziya Antona ot 6 avgusta (25 iyulya) 1872 goda]. Khristianskoe Chtenie [Christian Reading], (9), pp. 130-138. (rus)

Protopriest Popov, E. (1904). The Letter to Chief Procurator of The Most Holy Governing Synod earl N.A. Protasov on December 26 th, 1843. [Pis'mo protoiereya E.I. Popova Ober-prokuroru Svyatěshego Sinoda grafu N.A. Protasovu] Khristianskoe Chtenie [Christian Reading], (4), p. 600. (rus)

Protopriest Razumovsky, G. (1948). The ecumenical movement and the Russian Orthodox Church [Ékumenicheskoe dvizhenie i Russkaya Pravoslavnaya Tserkov']. Deyaniya Soveshchaniya glav i predstavitelei avtokefal'nuikh pravoslavnuikh tserkveǐ v svyazi s prazdnovaniem 500-letiya avtokefalii russkol pravoslavnol tserkvi. [Acts of the Conference of heads and delegates of the autocephalous Orthodox churches on the score of the celebration of the 500th anniversary of the autocephaly of the Russian Orthodox Church] [online] Retrieved from: http://krotov.info/history/20/1940/1948 07.htm [Accessed: 10 Jun 2013]. (rus)

Pushkin, A. (1941). The Letter to P.A. Vyazemskiĭ on June 1, 1831 [Pis'mo A.S. Pushkina k P.A. Vyazemskomu ot 1 iyunya 1831 g.]. In: Pushkin, A. eds. (1941). Polnoe sobranie sochineniĭ v 16-ti tomakh. T. 14. Perepiska, 1828-1831. [The Complete Collection of the Works in 16 volumes. Vol. 14. The Correspondence, 1828-1831]. Moscow, Saint Petersburg: Izdatel'stvo AN SSSR, pp. 169-170. (rus)

Reply of the Orthodox Eastern Church on the Encyclical Letter of Pope Pius IX to the Orthodox in the East, The [Otvet PravoslavnoI VostochnoI Tserkvi na Okruzhnoe poslanie papui rimskogo Piya IX k pravoslavnuim na Vostoke]. (1849). Pribavleniya k Tvoreniyam sv. Ottsov [Additions to the Works of the Holy Fathers], 1 (8). (rus)

Report of the British Greek-Russian Committee, The [Otchët britanskogo greko-russkogo komiteta]. (1882). Khristianskoe Chtenie [Christian Reading], (7-8), p. 122. (rus)

Report of the North American Greek-Russian Committee, The [Otchët severoamerikanskogo greko-russkogo komiteta]. (1882). Khristianskoe Chtenie [Christian Reading], (7-8), pp. 123-125. (rus)

Report and the resolution of the North American General Convention of the Episcopal Church 1874, The [Otchët i rezolutsiya severoamerikanskoĭ General'noĭ Konventsii Episkopal'noi Tserkvi 1874 goda]. (1883). Khristianskoe Chtenie [Christian Reading], (9-10), pp. 373-374. (rus)

Sokolov, P. (1897). The Adherent of the Beginning of the Old Catholic Church in the last century [Pobornik nachal starokatolitsizma v proshlom stoletii]. Khristianskoe Chtenie [Christian Reading], (7), pp. 95-130. (rus)

Solovyov, V. (1911). Russia and the Universal Church [Rossiya i vselenskaya tserkov']. Moscow: Tipografiya A.I. Mamontova.

Spichakov, L. (1872). Orthodoxy and Roman Catholicism on the western edge of Russia [Pravoslavie i rimskoe katolichestvo na zapadnoi okraine Rossii]. Moscow: Universitetskaya tipografiya (Katkov i Kº na Strastnom bul'vare. (rus)

Tolstoy, D. (1877). Roman Catholicism in Russia. Vol. 2. [Rimskil̆ katolitsizm v Rossii: v 2 t. T. 2]. Saint Petersburg: Izdanie i tipografiya V.F. Demakova. (rus) 